\title{
Discussion on Improvement of Moral Education in Colleges and Universities from the Perspective of Happiness Education Theory*
}

\author{
Gaohe Wang \\ School of Marxism \\ Jinan University \\ Guangzhou, China 510632
}

\begin{abstract}
Happiness is the ultimate goal of human activity and the ultimate value of education. Moral education in colleges and universities is highly consistent with happiness education in purpose and content. It is a new idea to study moral education in universities from the perspective of happiness education theory, which aims at reflecting and correcting the ignorance of traditional moral education on human development and happiness, guiding college students to correctly understand and pursue happiness, cultivating their happiness ability and making them the creator and user of happiness in modern civilized society.
\end{abstract}

Keywords-happiness; happiness education; moral education in colleges and universities

\section{INTRODUCTION}

Happiness is the ultimate goal and value of all human activities. Education is deeply related to happiness. It can be said that all education should belong to happiness education. As an important part of education, the moral education in colleges helps students to pursue happiness is its fundamental purpose as well as its main content.

II. THE INTERNAL RELATIONSHIP BETWEEN MORAL EDUCATION AND HAPPINESS EDUCATION IN COLLEGES

\section{A. The Consistency Between the Purpose of Moral Education with Happiness Education in Colleges and Universities}

Happiness and education have an inherent consistency: happiness should be the aim of education, and good education promotes personal and public happiness. The purpose of moral education in colleges and universities is a multi-dimensional system with political, economic, cultural and human development purposes, which can be summed up as the dual purpose of moral education in colleges and universities, namely, the purpose of social development and the purpose of human development. Whether in social development or human development, it does not contradict with each other in realizing

*Fund Project: This article is a key project of college ideological and political subject of Jinan University: "Research on the integration of Xi Jinping's theory of ideological and political work in universities into the career development of university teachers - exemplified by the study of Jinan university", a contemporary achievement of teaching reform project in Jinan University" Research on Integration of $\mathrm{Xi}$ Jinping Thought on Socialism with Chinese Characteristics for A New Era into College Teaching". the ultimate goal of human and individual happiness but complements and benefits each other. To sum up, the purpose of moral education in colleges and universities is happiness. Moral education in colleges and universities need to find an effective entry point to combine the duality of its purposes, so that it can meet the requirements of social development as well as the needs of human development. This entry point is to build the purpose of moral education in colleges and universities on happiness. In this way, the purpose of moral education in colleges and universities not only meets the needs of individual development: to make individuals happy in their self-perfection, and their legitimate pursuit of happiness has made accumulation and contribution to the development of society; it also meets the needs of social development: to realize the welfare and value of the society and to enhance the welfare and happiness of individuals.

\section{B. The Compatibility Between the Content of Moral \\ Education and Happiness Education in Colleges and Universities}

The outlook on world, outlook on life and values of moral education in colleges and universities all contain the outlook on happiness. A healthy outlook on happiness requires the guidance of a correct outlook on world, outlook on life, values and morality. The outlook on the world in Marxism scientifically reveals the universal law of the development of nature, human society and human thinking, which requires people to respect the development law of nature, society and human itself. Human and individual happiness view is only right and desirable if it conforms to the law of natural, social and human development. If it goes against the law, it will lead to misfortune. Life philosophy refers to people's general views and fundamental attitudes towards the purpose and meaning of life. The outlook on the value of life is the core of life philosophy, and the value of life is the organic unity of selfvalue and social value. Happiness education itself contains an understanding of the value, purpose and meaning of life. The essence of human is not a fixed abstract object, but the sum of all social relations. As the existence of social relations, human beings must clarify their status and behavior rules in human beings and nature, human beings and society, and human beings. In order to realize personal value, it is necessary to provide beneficial values for the society and others, and help 
others obtain happiness in the process of creating personal happiness, because individual happiness is directly related to the happiness of others and is closely related to the public happiness of society. The existence of human beings is to guarantee happiness with morality. Whether a person can finally grasp happiness depends on his own virtue, and the cultivation of virtue depends on education. The moral education in colleges and universities aims to cultivate personal virtues such as self-love, endurance, bravery, modesty and self-independence to lead people to happiness with the aim of cultivating the moral character of people and the fine and complete human nature. By cultivating public virtues such as benevolence, honesty, justice, tolerance and gratitude, public happiness is enhanced in the noble moral life, which is accorded with happiness education.

\section{THE MAIN EXPRESSION OF HAPPINESS EDUCATION DEFICIENCY IN MORAL EDUCATION OF COLLEGES AND UNIVERSITIES}

\section{A. Separation of Moral Education from Life and Happiness of College Students}

Moral education in colleges and universities exists with the emergence of class and state, and historically it serves the ruling class. Proletarian college moral education is an important part of Marxism, which serves the proletarian party and the country. The moral education in colleges and universities in China serves to implement all kinds of the party's political tasks. In class society, political stability, national prosperity and social development are the goals that countless people with lofty ideals have strived for all their lives in history. It is essential to emphasize that the value of the individual lies in the realization of the needs of the state and in the promotion of social progress. This idea is also the concentrated reflection of social standard values in moral education in colleges and universities, which reflects the strong political attribute of moral education in colleges and universities. As we know, moral education in universities is also the main channel and main position for moral education to students. If the social function of moral education in colleges and universities is blindly amplified and too much emphasis is placed on political education, it will easily lead to the instrumentalization of moral education, causing human alienation and making it a tool to suppress human nature, thus ultimately damaging human happiness.

After the founding of the People's Republic of China, the long-term interference of "left" thought and the influence of traditional "public standard" thought seriously hindered the implementation of the happiness education policy. We used to strengthen political education and transform morality education into a tool serving politics. The dogmatization of morality education simply emphasizes the inculcation of moral principles and norms. It holds that morality is altruistic. It brings happiness to society and to others and has nothing to do with the students' own happiness. What's more, more unfavorable the behavior is to them, more favorable it is to others, and nobler the individual is. Any moral doctrine, whatever its internal persuasiveness or external authority is, will be a feeble and fruitless doctrine unless it finds its own firm fulcrum in human moral nature. If morality is only for the happiness of others and has nothing to do with one's own happiness, then moral education loses the most fundamental human basis on which it depends. Such moral education tends to flow into high and empty formalism. People choose morality in order to better develop themselves, realize their ideal personality, and get the satisfaction of material happiness and spiritual happiness. The appeal of morality to college students should be closely related to their life and emotional needs. It should be able to cultivate their life interest and attitude, be conducive to the socialization of students, and enable them to have more ability to adapt to the society and to become happy persons. Even if the emphasis is on politics, it cannot be simply politics. The essence of politics is to contribute to students' happy life.

\section{B. The Lack of Guidance in Moral Education of Colleges and Universities to the Outlook on Happiness of College Students}

A survey of college students' happiness shows that their subjective happiness is significantly lower than that of young people in the same age in society. There are many reasons for this, among which employment, study pressure, and emotional perplexity of men and women have become the three major "happiness shortfalls" of college students. At the same time, they are in the period of the accelerating social transformation in China. The phenomena of hedonism, nihilism of value and demoralization make the traditional concept of moral and welfare be dispelled. People regard other things to be happiness other than virtue, such as money, fame, status, etc. Without moral constraints on human desire, materialism, money worship, individualism and hedonism are prevailing, which greatly impact the spiritual world of college students, and they lose their happiness. Behind the various reasons, there is a deep question, which is that college students have fallen into a misunderstanding of what true happiness is and how to get it. Some morbid happiness ideas spread among college students, such as "having money is happiness", "marrying a rich man is better than doing well in study". These phenomena and concepts reflect the problems in their understanding of happiness. As moral education has long been ideological, moral education in colleges and universities has trained college students to serve the political and social people, missing its role in the guidance for college students' happy life. With the advancement of market economy, while the university is in line with the market, the mechanism and management of market economy are also introduced by the university, which makes utilitarianism values permeate into all aspects of the university, having a lot of negative impact on the moral education of the university. Schools shape students according to market and social technology needs, and this talent cultivation model is just like the products produced on the same assembly line, with the same specifications and performance. There are unified requirements and management for students, teachers are taught in accordance with unified requirements, and standardized answers for tests cannot be deviated. The students shaped in such a training mode lose their personal development, lack free thought and independent spirit, and finally fail to get happiness. Under the background of moral empty and market orientation, moral education in colleges and universities serves economic development and 
lacks respect for human nature, care for emotions and healthy happiness guidance. Students are lack of spiritual development and growth. After leaving the society, they only know how to make a living, becoming a tool to make money, and a real economic man. They are pursuers in the field of fame and wealth, unable to find spiritual home and happy home in the creation of material wealth. As technology loses its moral guidance, some of them will even do things harmful to society, becoming "dangerous stuff" without virtue and turn their backs on happiness in immoral life.

\section{THE CONSTRUCTION PATH OF HAPPINESS EDUCATION IN MORAL EDUCATION OF COLLEGES AND UNIVERSITIES}

\section{A. Transforming the Concept of Moral Education in Colleges and Strengthening the Cultivation of Happiness Ability of College Students}

Under the guidance of practical materialism, the concept of moral education in colleges and universities is transformed from the basic problems facing moral education in China, which turns the object-oriented education view making people a tool into a people-oriented education view. In this way, human nature and happiness enter the perspective of the new college moral education, endowing moral education with life and soul. College students are not mature enough in knowledge, life experience and other aspects, and lack the ability to be happy. Education is indispensable to the cultivation of their ability to be happy.

First is to develop their ability to find and feel happiness. Happiness is in essence an individual's subjective feeling. Everyone seeks happiness, but not everyone can achieve it. According to a series of studies conducted by American psychologists Lehnen and Sid, goals of internal spiritual needs, such as personal growth, self-worth, others' praise, spiritual freedom, autonomy and self-discipline, good friendship and social service, are important foundations for happiness generation. The goals of external utilitarian needs, such as money, honor, conspicuous consumption and physical attraction, are instrumental and do not produce deep and lasting happiness. Age, sex, and income (as long as they are necessary for life) are not necessarily related to happiness. In today's materialistic world, quite a few college students attach too much importance to material well-being and lack the ability to discover and sense spiritual well-being. Therefore, moral education should pay more attention to the spiritual world of college students and improve their ability to perceive spiritual happiness. On the one hand, cultivate the morality of college students. Aristotle stressed that "virtue is happiness". The moral education in colleges and universities should not only talk about the concept of happiness for the sake of happiness, but should cultivate their moral personality, so that the moral character is internalized into their ideological realm and inner feelings and externalized into their lifestyle and behavior. Use morality to guide their attitude towards material things. "Great virtue carrying objects", without virtue we cannot bear long-term material happiness. "You cannot be rich after three generations" is a strong proof. The pursuit of happiness should not be limited to the narrow field of material things. Instead, it should be found and felt in a broader spiritual vision to achieve the win-win result of personal and others, themselves and society, material and spiritual life. On the other hand, cultivate the positive personality of college students. The ability to be happy has a lot to do with one's personality. The personality traits of a happy person include self-esteem, restraint, optimism and extroversion. There is no lack of happiness in life, what is lacking is the ability of the discovery and feeling of happiness. People with a positive personality don't ask for too much from life and are content with that they already have, and often have unexpected discoveries and surprises about happiness. For example, the singing of birds and the flavor of flowers, the letters from friends and the care of relatives can make them feel happy. They are easy to get along with people, having harmonious interpersonal relations, being good at sharing happiness and joy, and being good at using social support, easing pain and misfortune. Positive personality has inherent factors and needs to be cultivated. Moral education in colleges and universities should constantly optimize the personality quality of college students.

Second, the ability to create and enjoy happiness. Creation is not only an important means to obtain happiness, but also contains happiness itself. Happiness is not only a static result, but also a dynamic process. It is difficult for people to relate to happiness by breaking away the relationship between results and processes. To create happiness is also to enjoy happiness. If there is no happiness to enjoy but only to create it, it is useless to create happiness. Failure to strike a balance between giving and taking can also lead to misery in life. The process of creating happiness cannot be smooth. Pain and setbacks are the contradictions that often occur in the process of creating happiness. You cannot experience happiness without suffering. People have known happiness in the process of understanding pain, understood the principle of cherishing happiness, and the capacity for happiness has been improved in the contradiction of constantly enduring and overcoming pain. People with the capacity of happiness integrate creation and enjoyment, pain and happiness in the process of creating happiness. College moral education should guide college students to establish the concept of seeking happiness in the process, unify the creation and enjoyment of happiness in college moral education, guide them to treat pain correctly, regard it as part of life, and constantly transform it into the power and ability to pursue happiness.

\section{B. Fully Exploring and Innovating the Resources of Education in the Process of Moral Education in Colleges and Universities}

Educators, education receivers and education contents are the most basic elements in the process of moral education in colleges and universities.

First, the moral education courses in colleges and universities contain truth, kindness and beauty, and should be transformed into precious resources of happiness education. Moral education in colleges and universities is the work to satisfy people's demand for truth, goodness and beauty, and is a harmonious unification of the truth that conforms to the law, the goodness that accords with the purpose and the beauty that accords with the ideal. According to the curriculum system plan of 05 , there are five compulsory courses of moral 
education for college students: Introduction to Mao Zedong thought and the theoretical system of socialism with Chinese characteristics expounds the theoretical results of sinicization of Marxism produced by Chinese communists by combining the basic principles of Marxism with the concrete practice of China. Through the concrete and practical understanding of China's revolution, construction and reform and opening up, college students can realize their happiness are closely related to national weal and woe, so that they can love their country as they love themselves. They can have a unique life sentiment and realistic view of China's politics, economy, culture, society and ecology. Situation and policy education helps college students to understand the situation at home and abroad, guide them to comprehensively and accurately understand the party's line, principles and policies, grasp the pulse of The Times, shoulder the sacred mission of history, and consciously create happiness for the country and society. The outline of modern and contemporary history of China enables students to understand the great misfortune that modern China's humiliating history has caused to the Chinese nation and provides a mirror for modern society. It lets the college students use the sense of history to gain the observation and discrimination of things and enhance the sense of happiness today. "Ideological and moral cultivation and legal basis" emphasizes self-discipline and other-discipline, influences college students with standard behaviors, improves their personality, and constructs a complete and abundant spiritual happy world for them. An introduction to the basic principle of Marxism includes the philosophy of dialectical materialism and historical materialism, helping college students to deal with problems that cannot be solved by professional technology. It shows them the direction of a happy life, establish a firm life belief, so that they can both look up at the sky while setting their foot on the earth. In a word, we should be good at digging and using rich materials of education in moral education courses in colleges and universities to cultivate the happy personality of college students

Second, teachers and students jointly share the happiness of moral education in colleges and universities. In the process of moral education in colleges and universities, teachers and students should feel each other's happiness. Through vivid language, rational logic, clear order, full enthusiasm and humanistic feelings, the teacher cultivates the isomorphic psychological experience in the heart of the students. Such happy psychological experience strengthens teachers' happiness through students' expressions and emotional feedback. In this way, teachers and students' emotions collide and interact with each other, forming a strong emotional magnetic field. This mode of moral education in colleges and universities with emotion, reason and action has aroused students' interest and love for knowledge, stimulated the understanding, trust and care between teachers and students, and achieved unity in the creation and enjoyment of happiness. It has changed the traditional moral education of colleges and universities with mandatory, closed, one-way expression of emotion.

\section{CONCLUSION}

It is a new idea to pay attention to the happiness of college students in moral education. This "people-oriented" concept is a transcendence of the "material-oriented" concept of moral education in colleges and universities. It fully affirms the political and social functions of moral education in colleges and universities, while highlighting the purpose of human development and happiness. Political and social development is ultimately for human development and is the road to human happiness. Therefore, focusing on happiness education guides college students to correctly understand and pursue happiness, cultivates their happiness ability, makes them the creator and user of happiness in modern civilized society, realizes their comprehensive and free development, and all of which endows new tasks and contents of moral education in colleges and universities. It is also an urgent task to strengthen the actual effectiveness of moral education in colleges and universities.

\section{REFERENCES}

[1] Meng Jianwei. Education and happiness [J]. Education research 2010(2).

[2] Wu Shufeng. The practical significance of the study on happiness theory and subjective quality of life in multiple perspectives [J]. Journal of Wuhan University. 2004(5).

[3] Zhang Yu, Xing Zhanjun. A preliminary study on the subjective wellbeing of college students [J]. Journal of Shandong Youth League School. 2005 (4).

[4] Tan Chuanbao. On the happiness of teachers [J]. Education Science. 2002(1).

[5] Li Jiande. Research summary of six frontier problems of moral education in colleges and universities [J]. Journal of Xi 'an Institute of Politics. 2012(3). 